\title{
Tindak Tutur Ilokusi Penjelasan Presiden Joko Widodo mengenai Perkembangan Penanganan Covid-19 di Indonesia
}

\author{
Pradicta Nurhuda \\ pradicta.nurhuda@kemdikbud.go.id \\ Badan Pengembangan dan Pembinaan Bahasa
}

\begin{abstract}
Abstrak
Penelitian ini secara khusus membahas tentang jenis dan fungsi tindak tutur ilokusi yang terdapat dalam penjelasan Presiden Joko Widodo mengenai perkembangan penanganan Covid-19 di Indonesia pada tanggal 4 Maret 2021. Penelitian ini menggunakan metode deskriptif kualitatif dengan analisis pragmatik. Sumber data dalam penelitian ini adalah penjelasan Presiden Joko Widodo mengenai perkembangan penanganan covid-19 di Indonesia yang disiarkan di youtube Sekretariat Kabiner RI pada tanggal 4 Maret 2021. Hasil penelitian menunjukkan sebagai berikut. (1) Jenis tindak tutur ilokusi yang ditemukan adalah jenis tindak tutur asertif, direktif, ekspresif, komisif, dan deklaratif. (2) Fungsi tindak tutur ilokusi sebagai berikut: (a) tindak tutur asertif terdiri atas menyatakan, menyarankan, melaporkan, dan mengakui; (b) tindak tutur direktif terdiri atas memerintah, memohon, menganjurkan, dan merekomendasi; (c) tindak tutur ekspresif terdiri atas mengucapkan selamat dan memuji; (d) tindak tutur komisif terdiri atas menjanjikan, menawarkan, dan mengusulkan; dan (e) tindak tutur deklaratif yaitu mengizinkan.
\end{abstract}

Kata kunci: tindak tutur, ilokusi, penjelasan Presiden Joko Widodo,

\section{PENDAHULUAN}

Sejak ditemukan Covid-19 di Tiongkok pada akhir tahun 2019, negara-negara dunia merasakan dampak virus ini sampai saat ini. Bahkan, kabarnya penyakit ini susah disembuhkan jika sudah menjangkiti tubuh manusia. Salah satu negara di dunia yang merasakan dampak Covid-19 adalah negara Indonesia. Berbagai cara sudah dilakukan oleh Indonesia untuk menghentikan penyebaran virus ini, dari mulai menyosialisasikan protokol kesehatan 3M (mencuci tangan dengan sabun, memakai masker, dan menjaga jarak) serta membatasi pergerakan masyarakat melalui Pembatasan Sosial Berskala Besar (PSBB) dan Penerapan Pembatasan Kegiatan Masyarakat (PPKM). Upaya tersebut tampaknya masih belum efektif untuk menurunkan kasus Covid-19 karena setiap harinya korban positif Covid-19 terus bertambah.

Upaya terbaru yang dilakukan Pemerintah Indonesia untuk menurunkan korban Covid-19 adalah dengan memberikan vaksin kepada masyarakat. Vaksinasi Covid-19 bertujuan untuk menciptakan kekebalan tubuh terhadap Covid-19 sehingga akan tercipta kekebalan kelompok (herd immunity). Karena sangat pentingnya, Presiden Joko Widodo memberikan penjelasan langsung mengenai pentingnya program vaksinasi Covid-19 ini. Berkaitan dengan penjelasan yang disampaikan oleh Presiden Joko Widodo, banyak hal yang dapat dibahas, salah satunya adalah dari segi tindak tuturnya.

Salah kajian dalam pragmatik adalah tindak tutur yang berguna untuk mengkaji bahasa dari segi pemakaian yang masih baru (Hardiati, 2018:124). Selanjutnya, Putrayasa (2014:86) mengatakan bahwa tindak tutur merupakan penggunaan bahasa yang dilakukan penutur kepada petutur dalam mengomunikasikan sesuatu. Sementara itu, Ad-Darraji, dkk, (2012:1) mengatakan bahwa "The speech acts of any language provide its speakers with culture-specific categories of verbal interaction." Oleh karena itu, penelitian ini mengkaji tindak tutur yang berpeluang menghasilkan suatu tindakan dan memiliki pengaruh terhadap apa yang dilakukan oleh mitra tuturnya. Sama halnya dengan Presiden Jokowi, tuturan beliau tentu memiliki maksud tertentu. Penjelasan yang disampaikan Presiden Joko Widodo terhadap masyarakat dengan memiliki maksud tertentu tersebut dapat dikategorikan dalam jenis tindak tutur ilokusi.

Berdasar pada latar belakang yang telah dijelaskan di atas, peneliti tertarik untuk meneliti penjelasan Presiden Joko Widodo mengenai perkembangan penanganan Covid-19 di Indonesia yang disampaikan di youtube Sekretariat Kabinet RI pada tanggal 4 Maret 2021 dari segi tindak tutur. Tindak tutur yang akan diteliti lebih dalam dalam penelitian ini adalah bentuk tindak tutur ilokusi. Oleh karena itu, peneliti memberikan judul pada penelitian ini, yaitu Tindak Tutur Ilokusi Penjelasan Presiden Joko Widodo mengenai Perkembangan Penanganan Covid-19 di Indonesia.

\section{LANDASAN TEORI}

Pragmatik merupakan cabang linguistik yang mempelajari suatu tuturan yang memiliki makna sesuai dengan konteks pada saat tuturan disampaikan. Menurut Nunan dalam Jumanto (2017:40), pragmatik adalah 
ilmu mengenai penggunaan bahasa dalam suatu konteks dalam mencapai suatu tujuan. Selanjutnya, Yule dalam Jumanto (2017:40) mengatakan bahwa pragmatik merupakan ilmu tentang makna dalam komunikasi oleh penutur yang ditafsirkan oleh petutur mencakup makna penutur, kontekstual, tersembunyi, dan ungkapan tentang jarak relatif antara penutur dan petutur. Lebih lanjut Leech (dalam Nadar, 2009:7) menambahkan bahwa dalam kajian pragmatik, konteks adalah sangat penting.

Tindak tutur merupakan unsur pragmatik yang mengkaji makna bahasa dengan melibatkan hubungan antara penutur dan petutur dengan melihat konteks tuturannya. Suatu tuturan yang diucapkan oleh penutur kepada petutur pasti memiliki maksud dan tujuan tertentu, apakah itu bersifat pemberitahuan, pertanyaan, ajakan, dll.. Menurut Yule (2006:81-82), tindak tutur adalah semua tindakan yang dilakukan melalui tuturan. Selanjutnya, menurut Chaer (2010:61), tuturan adalah alat penting komunikasi antardua pihak yang memiliki makna nyata dalam bentuk ujaran pada keadaan tertentu. Lebih lanjut, menurut Chaer dan Agustina (2010:50), tindak tutur merupakan tuturan yang mempunyai sifat psikologis dan keberadaannya ditentukan oleh kemampuan berbahasa penutur dalam menghadapi situasi tertentu. Senada dengan pendapat tersebut, menurut Searle (dalam Rusminto, 2010:74-75), tindak tutur adalah suatu teori yang mengkaji maksud bahasa penutur berdasarkan hubungan antara tindakan dan tuturannya. Simpulan dari pengertian-pengertian di atas tindak tutur adalah media komunikasi yang disampaikan penutur sesuai dengan situasi dan konteks yang memiliki makna tertentu pada saat tuturan disampaikan.

Austin (dalam Rusminto, 2010:22 - 23) menggolongkan tindak tutur menjadi tiga, yaitu tindak tutur lokusi, ilokusi, dan perlokusi. Selanjutnya, Searle (dalam Rusminto 2010:22) mengklasifikasikan tindak tutur ilokusi menjadi lima bentuk tuturan, yaitu (1) asertif adalah bentuk tuturan yang mengikat kebenaran ungkapan penutur, seperti: mengklaim, mengeluh, membual, menyarankan, dan menyatakan; (2) Direktif adalah bentuk tuturan yang membuat pengaruh kepada petutur agar petutur melakukan tindakan yang diinginkan penutur, seperti: merekomendasi, memohon, memesan, menasehati, dan memerintah; (3) Ekspresif adalah bentuk tuturan yang menyatakan sikap psikologis penutur pada situasi tertentu, seperti: berbelasungkawa, menyalahkan, meminta maaf, memuji, berterima kasih, dan memberi selamat; (4) Komisif adalah bentuk tuturan untuk menyatakan penawaran atau ketentuan, seperti: menawarkan, berjanji, dan bersumpah; (5) Deklarasi adalah bentuk tuturan yang antara isi tuturan dan kenyataan berhubungan, seperti: menghukum, mengangkat, berpasrah, memecat, memberi nama, membaptis, dan mengucilkan.

Penelitian tentang tindak tutur ilokusi pernah dilakukan oleh Kurniati (2014) berjudul Tindak Tutur Ilokusi pada Pesan Singkat (SMS) Bermotif Penipuan. Hasil penelitian ini adalah tindak tutur ilokusi yang termuat dalam pesan singkat (SMS) yang mempunyai motif penipuan. Adapun pesan yang mempunyai motif penipuan ada empat tindak tutur, yaitu tindak tutur asertif, ekspresif, direktif, dan deklaratif, sementara tindak tutur yang tidak ditemukan dalam data adalah tindak tutur komisif. Selain itu, dalam pembahasan juga ditemukan dua tindak tutur direktif, yaitu tindak tutur direktif langsung dan tindak tutur direktif tidak langsung.

Penelitian tindak tutur ilokusi lain juga pernah dilakukan oleh Septi Nur Azizah (2019) berjudul Tuturan Ilokusi dalam Wacana Pidato Kampanye Prabowo Subianto pada Pemilu 2019. Pembahasan dalam penelitian ini adalah (1) jenis tindak tutur ilokusi yang ditemukan dalam data antara lain adalah tindak tutur representatif, direktif, ekspresif, komisif, dan deklaratif serta (2) fungsi tindak tutur ilokusi yang ditemukan dalam data antara lain adalah fungsi menyatakan, fungsi melaporkan, fungsi menyebutkan, fungsi mengakui, fungsi meminta, fungsi menyuruh, fungsi memohon, fungsi mengajak, fungsi mengucapkan terima kasih, fungsi menyalahkan, fungsi mengkritik, fungsi mengeluh, fungsi berjanji, fungsi bersumpah, dan fungsi melarang.

Penelitian tentang tindak tutur ilokusi penjelasan Presiden Joko Widodo ini termasuk dalam penelitian deskriptif kualitatif. Tujuan penelitian deskriptif adalah untuk mendapatkan deskripsi secara terperinci, sistematis, dan akurat terhadap suatu fakta (Zainuddin dalam Amar, 2010:53). Sementara itu, pendekatan kualitatif adalah pendekatan dalam penelitian yang berguna untuk memahami suatu fakta yang dialami subjek penelitian secara keseluruhan dengan cara memanfaatkan bermacam metode ilmiah melalui cara deskripsi kata-kata dan bahasa (Moleong, 2007:6). Jadi, penelitian ini berusaha untuk mendeskripsikan jenis dan bentuk-bentuk tindak tutur ilokusi penjelasan Presiden Joko Widodo mengenai Perkembangan Penanganan Covid-19 di Indonesia menggunakan kajian pragmatik.

Objek penelitian ini adalah tindak tutur ilokusi yang terdapat dalam penjelasan Presiden Joko Widodo mengenai Perkembangan Penanganan Covid-19 di Indonesia yang disiarkan di youtube Sekretariat Kabiner RI pada tanggal 4 Maret 2021. Sudaryanto (dalam Nadar, 2009:107) mengatakan bahwa data merupakan fakta bahasa yang berhubungan langsung dengan masalah yang ditentukan. Dalam penelitian ini datanya adalah bentuk-bentuk tuturan yang berupa tindak tutur ilokusi yang disampaikan oleh Presiden Joko Widodo 
dalam youtube. Langkah-langkah dalam pengumpulan data sebagai berikut: (1) mendengarkan video penjelasan Presiden Joko Widodo mengenai Perkembangan Penanganan Covid-19 di Indonesia yang disiarkan di youtube Sekretariat Kabiner RI pada tanggal 4 Maret 2021; (2) menyimak tuturan Presiden Joko Widodo; dan (3) mentranskripsikan tuturan Presiden Joko Widodo dalam bahasa tulis.

Langkah-langkah yang dilakukan dalam menganalisis data adalah sebagai berikut: (1) mentranskripsikan tuturan Presiden Joko Widodo dalam bahasa tulis; (2) mengklasifikasikan berdasarkan jenis dan fungsi tindak tutur ilokusi penjelasan Presiden Joko Widodo mengenai Perkembangan Penanganan Covid-19 di Indonesia; (3) menganalisis data yang telah diklasifikasi; dan (4) melakukan penyimpulan hasil penelitian.

\section{HASIL PENELITIAN DAN PEMBAHASAN}

Dalam penelitian ini, peneliti menemukan lima jenis tindak tutur ilokusi, yaitu asertif, direktif, ekspresif, komisif, dan deklaratif.

\section{Asertif}

\section{a. Fungsi menyatakan}

"Bapak, Ibu, dan Saudara-saudara sebangsa dan se-Tanah Air,

Satu tahun pandemi Covid-19 telah melanda dunia, tidak terkecuali negara kita Indonesia. Berbagai usaha untuk menanggulangi pandemi terus kita lakukan."

Berdasarkan tuturan tersebut, presiden menyatakan bahwa sudah satu tahun pandemi Covid-19 melanda semua negara di dunia termasuk Indonesia. Presiden juga menyatakan bahwa pemerintah sudah melakukan berbagai usaha untuk menanggulangi pandemi Covid-19.

"Prioritas pemerintah sejak awal pandemi sudah sangat jelas, keselamatan dan kesehatan masyarakat adalah hal yang utama."

Berdasarkan tuturan tersebut, presiden menyatakan bahwa pemerintah mempunyai prioritas dari sejak awal adanya Covid-19, yaitu prioritas keselamatan dan kesehatan masyarakat.

\section{b. Fungsi menyarankan}

"Untuk itu, pemerintah terus melakukan upaya 3T; testing, tracing, dan treatment (tes, lacak, dan isolasi). Dan, masyarakat tetap harus melakukan protokol kesehatan 3M; memakai masker, mencuci tangan, menjaga jarak."

Berdasarkan tuturan tersebut, presiden menyarankan agar masyarakat tetap menerapkan protokol kesehatan 3M, yaitu memakai masker, mencuci tangan, dan menjaga jarak walaupun selama ini pemerintah terus melakukan upaya 3T, yaitu tes, lacak, dan isolasi. Yang disampaikan presiden mengandung makna bahwa upaya yang dilakukan pemerintah tidak akan berhasil tanpa ada peran serta masyarakat dalam menerapkan protokol kesehatan yang ketat.

\section{c. Fungsi melaporkan}

"Saat ini memang semua negara berebut vaksin. Semua negara berebut vaksin. Dan alhamdulillah karena awal-awal kita sudah melakukan pendekatan-pendekatan, baik secara pemerintah ke pemerintah $(G$ to $G)$ maupun langsung ke beberapa produsen vaksin. Hingga kini kita telah memiliki 38 juta dosis vaksin COVID-19. Tiga juta dosis vaksin dalam bentuk sudah jadi dan 35 juta dalam bentuk bahan baku vaksin."

Berdasarkan tuturan tersebut, presiden melaporkan bahwa semua negara di dunia berebut untuk mendapatkan vaksin Covid-19, tetapi karena pemerintah sudah melakukan berbagai pendekatan ke pemerintah negara lain secara langsung ataupun ke beberapa produsen vaksin, hingga kini Indonesia telah memiliki 38 juta dosis vaksin yang terdiri atas 3 juga dosis vaksin dalam bentuk sudah jadi dan 35 juta dosis vaksin dalam bentuk bahan baku. 


\section{d. Fungsi mengakui}

"Angka kematian per 3 Maret, Indonesia rata-rata kematian berada di angka 2,7 persen, dunia berada di angka 2,22 persen. Nah, ini yang harus kita perhatikan dan kita harus bekerja keras agar angka kematian di Indonesia bisa berada di bawah rata-rata angka kematian dunia."

Berdasarkan tuturan tersebut, presiden mengakui bahwa rata-rata kematian di Indonesia per tanggal 3 Maret 2021 adalah 2,7 persen, sedangkan di dunia rata-rata kematian Indonesia adalah 2,22 persen. Untuk itu, presiden mengajak masyarakat Indonesia untuk bekerja keras dalam menerapkan protokol kesehatan yang ketat agar angka kematian di Indonesia bisa berada di bawah rata-rata angka kematian dunia.

\section{Direktif}

\section{a. Fungsi memerintah}

"Di kementerian-kementerian juga sudah saya perintahkan dan juga sudah dimulai 1 Maret yang lalu. Juga untuk atlet, sudah mulai diberikan suntikan vaksinasi."

Berdasarkan tuturan tersebut, presiden secara tersurat memerintahkan kementerian-kementerian untuk melakukan vaksin Covid-19. Presiden juga menjelaskan bahwa vaksin Covid-19 diberikan di kementerian mulai 1 Maret. Selain itu, presiden secara tersirat juga memerintahkan atlet untuk diberikan vaksin Covid-19 yang saat ini sudah mulai diberikan.

"Terkait dengan program vaksinasi, saya juga telah mengingatkan dan meminta pemerintah daerah untuk lebih cepat, untuk lebih giat lagi melaksanakan vaksinasi di daerah masing-masing, agar kita segera sesegera mungkin dapat membentuk kekebalan kelompok/herd immunity."

Berdasarkan tuturan tersebut, presiden secara tidak langsung memerintah kepala daerah untuk lebih cepat dan giat untuk melaksanakan vaksinasi Covid-19 di daerahnya sehingga secepatnya akan terbentuk kekebalan kelompok (herd immunity).

\section{b. Fungsi memohon}

"Berbagai usaha untuk menanggulangi pandemi terus kita lakukan. Dan, tentunya Pemerintah tidak mungkin dapat bekerja sendiri mengatasi pandemi ini. Perlu dukungan dan kebersamaan dari semua pihak, terutama masyarakat."

Berdasarkan tuturan tersebut, presiden secara tersirat memohon kepada semua pihak, terutama masyarakat untuk bersama-sama mengatasi pandemi Covid-19 karena pemerintah tidak dapat bekerja sendiri dalam mengatasi pandemi ini.

\section{c. Fungsi menganjurkan}

"Pencegahan agar tidak tertular virus dengan varian baru ini juga telah kita lakukan bersama-sama. Untuk itu, mari kita tetap berdisiplin menjalankan protokol kesehatan dengan ketat seiring dengan pelaksanaan vaksinasi yang semakin cepat."

Berdasarkan tuturan tersebut, presiden menganjurkan kepada semua masyarakat agar tetap berdisiplin menjalankan protokol kesehatan secara ketat agar tidak tertular virus Covid-19 varian baru.

\section{d. Fungsi merekomendasikan}

"Dan kita tahu saat ini vaksinasi telah dilakukan dengan memprioritaskan masyarakat dengan risiko tinggi. Untuk itu, yang pertama divaksinasi adalah tenaga kesehatan, kemudian yang lanjut usia, dan juga petugas dan pelayan publik."

Berdasarkan tuturan tersebut, presiden merekomendasikan bahwa pemberian vaksin Covid-19 diprioritaskan bagi masyarakat dengan risiko tinggi sehingga presiden merekomendasikan bahwa yang divaksin pertama adalah tenaga kesehatan, selanjutnya orang tua yang lanjut usia, dan selanjutnya petugas dan pelayan publik. 


\section{Komisif}

\section{a. Fungsi menyatakan janji}

"Target vaksinasi pada periode Januari sampai Juni adalah 40 juta orang. Dan kita menargetkan satu juta orang harus divaksinasi setiap hari, agar pelaksanaan vaksinasi ini dapat selesai tepat waktu sesuai target yang telah kita berikan."

Berdasarkan tuturan tersebut, presiden menargetkan dan secara tidak langsung menyatakan janji bahwa vaksinasi Covid-19 pada periode Januari sampai Juni adalah 40 juta orang. Presiden juga menargetkan dan secara tidak langsung menyatakan janji bahwa satu juta orang diberikan vaksin Covid-19 setiap hari.

\section{b. Fungsi menawarkan}

"Karena percepatan vaksinasi menjadi salah satu kunci untuk mengendalikan laju penularan Covid-19 untuk mengendalikan pandemi ini."

Berdasarkan tuturan tersebut, presiden menawarkan bahwa percepatan vaksinasi Covid-19 menjadi salah satu kunci untuk mengendalikan laju penularan Covid-19.

\section{c. Fungsi mengusulkan}

"Oleh karena itu, vaksinasi ini tidak hanya di Jakarta tapi harus terus bergulir ke semua provinsi, ke semua kabupaten, ke semua kota: Jakarta, Banten, Jawa Barat, Jawa Tengah, Daerah Istimewa Yogyakarta, Jawa Timur dilanjutkan dengan Bali, Nusa Tenggara Timur, Nusa Tenggara Barat, Sumatra, Kalimantan, Sulawesi, Maluku, dan Papua."

Berdasarkan tuturan tersebut, presiden mengusulkan bahwa vaksin Covid-19 tidak hanya diberikan di Jakarta, tetapi di seluruh provinsi yang ada di Indonesia. Dalam tuturan yang disampaikan oleh presiden hanya 14 provinsi yang disebutkan akan mendapatkan vaksin, tetapi sebenarnya presiden menginginkan dan mengusulkan bahwa seluruh provinsi di Indonesia akan mendapatkan vaksin Covid-19.

\section{Ekspresif}

\section{a. Fungsi mengucapkan selamat}

"Penurunan penambahan jumlah kasus positif dalam satu minggu terakhir ini juga menunjukkan tren yang semakin baik, tren menurun."

Berdasarkan tuturan tersebut, presiden secara tersirat mengucapkan selamat kepada semua pihak bahwa jumlah kasus positif Covid-19 dalam satu minggu terakhir menunjukkan tren menurun. Hal itu menurut presiden menunjukkan tren yang semakin baik.

\section{b. Fungsi memuji}

"Hingga saat ini, alhamdulillah, Pemberlakuan Pembatasan Kegiatan Masyarakat (PPKM) Skala Mikro di Pulau Jawa dan Bali telah menunjukkan hasil."

Berdasarkan tuturan tersebut, presiden secara tersirat memuji kepada daerah di Pulau Jawa dan Bali yang telah menerapkan PPKM sehingga tren korban positif Covid-19 semakin menurun.

"Penambahan kasus mingguan di tujuh provinsi; di DKI Jakarta, di Provinsi Banten, di Provinsi Jawa Barat, di Provinsi Jawa Tengah, di Provinsi Daerah Istimewa Yogyakarta, di Provinsi Jawa Timur, dan di Provinsi Bali, kelihatan sekali trennya terus menurun. Ini sangat bagus. Dan kita harapkan kita terus tetap bekerja keras agar tren laju penurunan ini bisa turun, turun, dan terus turun." 
Berdasarkan tuturan tersebut, presiden secara tersirat memuji kepada tujuh provinsi yang memiliki kasus mingguan terus menurun. Presiden juga mengharapkan agar semua pihak terus bekerja keras agar kasus Covid-19 ini terus menurun.

\section{Deklaratif}

\section{a. Fungsi mengizinkan}

"Kita ingat di (Pasar) Tanah Abang sudah dilakukan. (Pasar) Tanah Abang di Jakarta dan juga di Pasar Beringharjo dan kawasan Malioboro di Jogja, juga telah dimulai vaksinasi."

Berdasarkan tuturan tersebut, presiden secara tersirat mengizinkan bahwa Pasar Tanah Abang, Pasar Beringharjo dan kawasan Malioboro telah mulai diberikan vaksin Covid-19.

\section{SIMPULAN}

Berdasarkan hasil penelitian dan pembahasan di atas, peneliti menyimpulkan sebagai berikut:

1. Jenis tindak tutur ilokusi yang ditemukan dalam penjelasan Presiden Joko Widodo mengenai perkembangan penanganan Covid-19 di Indonesia yang disiarkan di youtube Sekretariat Kabinet RI pada tanggal 4 Maret 2021 adalah jenis tindak tutur asertif, direktif, ekspresif, komisif, dan deklaratif.

2. Fungsi tindak tutur ilokusi dalam penjelasan Presiden Joko Widodo mengenai perkembangan penanganan Covid-19 di Indonesia yang disiarkan di youtube Sekretariat Kabinet RI pada tanggal 4 Maret 2021 adalah sebagai berikut: (a) tindak tutur asertif terdiri atas menyatakan, menyarankan, melaporkan, dan mengakui; (b) tindak tutur direktif terdiri atas memerintah, memohon, menganjurkan, dan merekomendasikan; (c) tindak tutur ekspresif terdiri atas mengucapkan selamat dan memuji; (d) tindak tutur komisif terdiri atas menjanjikan, menawarkan, dan mengusulkan; dan (e) tindak tutur deklaratif yaitu mengizinkan.

\section{DAFTAR PUSTAKA}

Ad-Darraji, H., Foo, T., Ismail, S., \& Abdulah, E. 2012. Offering as a Comissive and Directive Speech Act: Consequence for Cross-Cultural Communication. International Journal of Scientific and Research Publications, Volume 2 (3), page 1-6.

Amar, Noezafri. 2010. Praanggapan dan Implikatur pada Wacana Lisan dalam Acara Mata Najwa di Metro TV. Madah, 1 (1): 49-60.

Azizah, Septi Nur. 2019. Tuturan Ilokusi dalam Wacana Pidato Kampanye Prabowo Subianto pada Pemilu 2019. Skripsi. Tidak Diterbitkan. Jurusan Bahasa dan Sastra Indonesia. Fakultas Bahasa dan Seni. Universitas Negeri Semarang.

Chaer, Abdul dan Leonie Agustina. 2010. Sosiolinguistik Perkenalan Awal. Jakarta: Rineka Cipta.

Chaer, Abdul. 2010. Kesantunan Berbahasa. Jakarta: PT Rineke Cipta.

Hardiati, Wiwin. 2018. Tindak Tutur Sarkastik di Media Sosial. Jurnal Bahasa, Sastra, dan Pembelajarannya, 8 (1): 123-131.

Jumanto. 2017. Pragmatik: dunia linguistik tak selebar daun kelor. Yogyakarta: Morfalingua.

Kurniati, Ai. 2014. Tindak Tutur Ilokusi pada Pesan Singkat (SMS) Bermotif Penipuan. Suar Betang, IX (1): $67-75$.

Moleong, Lexy J.. 2007. Metodologi Penelitian Kualitatif. Bandung: PT Remaja Rosdakarya Offset.

Nadar, F.X. 2009. Pragmatik dan Penelitian Pragmatik. Yogyakarta: Graha Ilmu.

Putrayasa, Ida Bagus. 2014. Pragmatik. Yogyakarta: Graha Ilmu.

Rusminto, Nurlaksana Eko. 2010. Analisis Wacana: Kajian Teoritis dan Praktis. Bandar Lampung. Universitas Lampung.

Yule, George. 2006. Pragmatik. Yogyakarta: Pustaka Pelajar. 